Earth is that it is "the most scientific inquiry into the future ever organized"'. This seems unsupportable, if only because it is doubtful whether any estimate of the future thus far published can be shown to be "the most scientific". Is this a creditable boast for a publication never subjected to peer review? I would contend that none of the projections of the future made thus far are "scientific" except and in so far as they are based upon the best available scientific evidence. Any projection of the future is fraught with uncertainty and the possibility of error - neither Global 2000 nor The Resourceful Earth are exceptions.

Allowing a limited validity to the aphorism "a little knowledge is dangerous", a little valid knowledge today may be greatly preferable to common-sense ignorance. The extraordinary growth of scientific knowledge during the past quarter-century provides more and better data than that heretofore available for assessing future trends. But the data do not automatically provide this assessment neither do the science specialists who develop the data. Individual scientists, including contributors to The Resourceful Earth, are prepared to set forth the findings of their specialities but are not necessarily prepared or able to relate them to findings in other disciplines. The global models that Kahn and Simon disparage are attempts to develop syntheses among diverse but related scientific findings - an enterprise hardly possible before the development of powerful and sophisticated computers. Whether this modelling is "science" or merely technique may be a matter of definition; whatever it may be called, it is a relatively recent development. Yet even with its inevitable imperfections (which only experience can correct) it is surely more reliable than Kahn and Simon's simplistic ruler-and-pencil trend analysis.

The foregoing observations indicate where I believe The Resourceful Earth has failed to measure up to its billing. But what of its one-quarter success? To me, its limited merit is the occasion which it provides for a careful, critical examination of the conclusions that it purports to refute, and the data it has assembled in the respective contributions on a range of environmental issues. I regard the assumptions of its editors as wrong, but nonetheless deserving of open-minded examination. The Kahns and Simons of the environmental movement are for their part not without comparable sin. In responding to the allegations of The Resourceful Earth, the environmentalists may discover shortcomings in their own analysis and be pressed to state more precisely why Global 2000 and its associated literature deserve to be taken seriously.

Lvmon K. Caldwell is Bentlev Professor of Political Science at Indiana Universitv. His most recent book is Internariunal Environmental Puicy: Resources and Dimensions (Duke Universitv Press, 1984).

\section{Making war on the world}

\section{Alastair Hay}

Environmental Warfare: A Technical,

Legal \& Policy Appraisal.

Edited by Arthur H. Westing.

Taylor \& Francis: 1984. Pp. 107. £12,

$\$ 21$.

Herbicides in War: The Long-Term

Ecological and Human Consequences. Edited by Arthur $\mathrm{H}$. Westing.

Taylor \& Francis: 1984. Pp. 210. f15,

$\$ 33$.

SEEDING clouds to increase rainfall, breaching reservoirs to cause flooding and denuding forests with herbicides are some of the better known techniques of environmental warfare. All three activities were carried out by US armed forces in Vietnam. Cloud seeding was a failure. Dykes which were breached on occasions caused some flooding, but this never seriously undermined North Vietnam's war effort. It was the defoliation programme which, as far as the US military was concerned, could be pronounced successful. Large tracts of naked forest provided no cover for the enemy and discouraged all movement in the area.

In war the object is to win. If this means destroying buildings or countryside, then history is replete with examples of military commanders who have not thought twice about razing an area; for the soldiers in the field it is a legitimate activity. But as wars become ever more destructive, and as awareness grows of the fragility of our environment, we must ask whether this form of warfare should be allowed to go unchecked.

Environmental Warfare and Herbicides in War are both edited volumes, emanating from the Stockholm International Peace Research Institute, which address these issues. If they have one message in common, it is that such practices cannot continue. The first book discusses the subject from a global perspective, whereas the second is concerned exclusively with assessing the impact of the military use of defoliants in Vietnam from 1962 to 1971.

Indochina has not been the only testing ground for some of these refinements of warfare, merely the latest. Dykes were breached in the Franco-Dutch war of $1672-1678$ to halt the progress of attacking French forces, and with some success. But the single most devastating act of destruction recorded was during the SinoJapanese war of 1937-1945, when, in June 1938, Chinese forces dynamited the Huayuankow dyke on the Yellow River. Several thousand Japanese soldiers drowned in the subsequent flood and the advance of the Emperor's forces on this front was stopped. The Japanese, however, were not the only victims. Hundreds of thousands of Chinese were also drowned, millions of acres of crops were destroyed and life on the banks of the Yellow River remained unsettled until 1947 when the river was once again brought under control. It is this latter point that is at the crux of any discussion of environmental warfare - the effects are indiscriminate. Non-combatants invariably bear a disproportionate number of the

\section{IMAGE \\ UNAVAILABLE FOR COPYRIGHT REASONS}

Chemical blitz - mangrove forest in South Vietnam before (top) and after spraying with herbicide.

casualties, and in Vietnam too it was the civilians that were the real losers.

Herbicides in War is the published proceedings of a conference held in Ho Chi Minh City (formerly Saigon) in January 1983. The meeting was called to assess the long-term effects of the defoliation programme and, as the book makes clear, those effects were devastating. During the spraying programmes, some $10.3 \%$ of Vietnam's inland forests, $36 \%$ of mangrove forests, $3 \%$ of cultivated land and $5 \%$ of other land was sprayed one or more times with a variety of "anti-plant agents". Some 19 million gallons of defoliants were used, the most common of them being Agents Blue, Orange and White - socalled because of the painted bands on the drums in which the herbicides were shipped to Vietnam.

The book contains the reports of working groups which evaluated the impact of the defoliants on Vietnam's ecology and on the health of the population, and the ways in which the toxic contaminant dioxin $(2,3,7,8$-tetrachlorodibenzodioxin) present in Agent Orange can be measured in the environment. The background to these subjects is provided, in the main, by 
Vietnamese scientists, while the overall findings are set in context by general overviews written by American, British and Swedish scientists. Their conclusions are that Vietnam's inland and mangrove forests not only suffered immediate and extensive damage as a result of the spraying, but that the effects persist. Only a replanting programme - already begun by the Vietnamese - on a massive scale will heal the scars of war. For this work to succeed time and international help will be required.

The effects of the various chemical agents on the health of the population is more difficult to judge. Vietnamese scientists believe that the herbicides caused an increase in the incidence of liver cancer and in the number of children born with handicaps. Regrettably it is too early to assess both claims; the evidence is still far from complete and much more information will need to be gathered to resolve the issue. Meanwhile the population of Vietnam has to live with uncertainty. It will be little consolation that the havoc visited upon their country has led to moves to prevent the same thing happening again elsewhere.

In 1977, outrage over the attempted manipulation of the environment of
Indochina went a stage further than mere condemnation, with the enactment of the Environmental Modification (ENMOD) Convention. The Convention was designed to prohibit acts of war intended to change the natural environment, but fell short of what was required. Environmental Warfare reviews the agreement and points out how the text of the 1977 drafting should be tightened to exclude totally any manipulation of the environment by armed forces (some is still permitted) and to outlaw research on methods of manipulation for hostile purposes.

In the heat of battle there will be no time, nor desire, to agree codes of conduct; such agreements need to hammered out in calmer times. A nuclear war, with the ensuing nuclear winter, may render some of these resolutions academic, but in the event of more conventional warfare we will be glad of them. These two publications will be invaluable for bringing that lesson home.

Alastair Hay is a Lecturer in the Department of Chemical Pathology at the University of Leeds. With Seán Murphy and Steven Rose, he is coauthor of No Fire, No Thunder: The Threat of Chemical and Biological Weapons (Pluto Press, 1984).

\section{Regulation damage}

\section{Anne H. Ehrlich}

Environmental Policy in the 1980s:

Reagan's New Agenda.

Edited by Norman J. Vig and Michael E.

Kraft.

Congressional Quarterly Inc., 1414 22nd Street NW, Washington DC 20037: 1984. Pp.377. Pbk \$12.95.

SINCE shortly after Ronald Reagan took office as President of the United States, environmentalists have protested that violence is being done to America's hardwon federal regulatory apparatus for environmental protection and resource management. The means, it is alleged, are administrative fiat and selective budgetslashing. Now a group of scholars with an impressive array of academic credentials has analysed the Reagan team's record in administering the government's resource and environmental programmes. They have produced a detailed indictment of that record, as resounding as anything so far issued by even the most militant of environmental organizations.

Some of the territory explored by Norman Vig, Michael Kraft and the 15 other contributors to this collection is familiar to the public. Most notably there have been the scandalous goings-on at the Environmental Protection Agency (EPA) - the reign and departure in disgrace of its administrator Anne Gorsuch-Burford, and the belated attempt to rescue the agency's remaining shreds of credibility by appointing William Ruckleshaus as its head in 1983 - not to mention the achievements of Reagan's remarkably insensitive (both socially and environmentally) first Secretary of the Interior, James G. Watt.

Meanwhile, however, other events of questionable legitimacy have occurred without attracting the limelight - the dismantling of the Department of Energy's information-gathering and research capabilities and its programmes to encourage conservation and development of alternative energy sources; the mutually contradictory policies of forest management in the Department of Agriculture; and the abdication of the nation's role of world leadership in environmental protection and global resource management. An example of the last, which did attract public attention but occurred too late for inclusion in this book, was the Reagan administration's ludicrous performance at the United Nations' World Population Conference last August in Mexico City.

Vig, Kraft and their co-authors scrutinize these and other actions, the effect (and, evidently, intent) of which has been to weaken, if not cripple, the environmental regulatory power of the federal government. The book also presents a history of environmental legislation and regulation at the federal level, a discussion of the misconstrued electoral "'mandate" for the sweeping changes that were effected, and an assessment of the long-term damage inflicted on the government's institutions by the Reagan regime in just three years.

The administration's attempts to revise

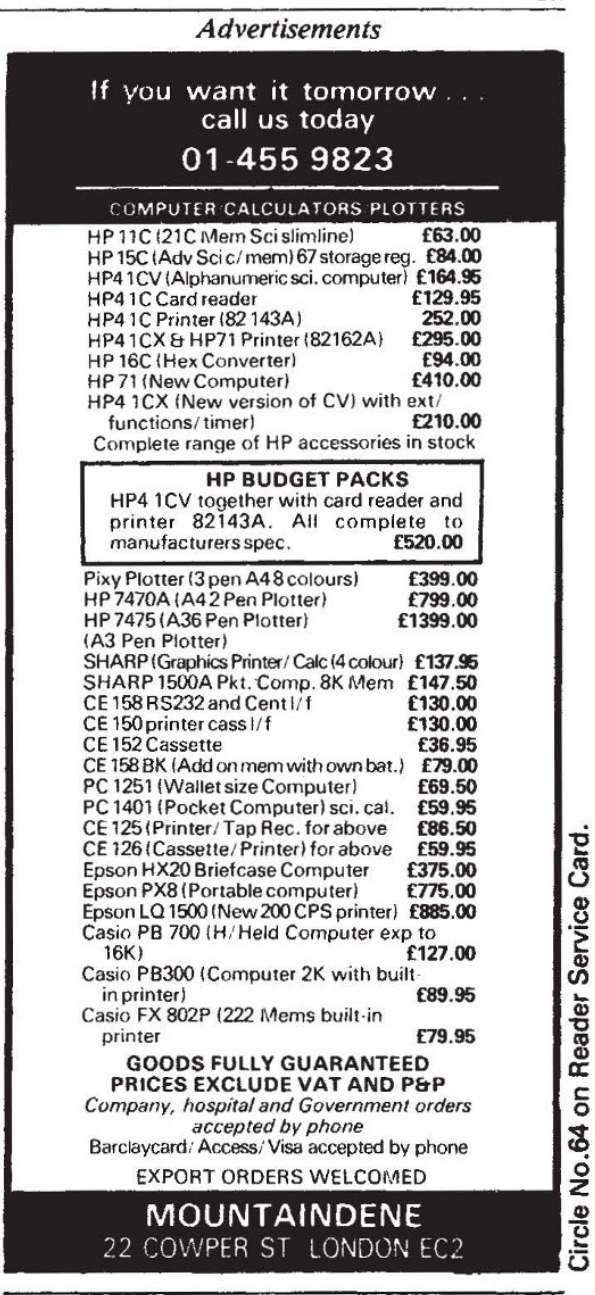

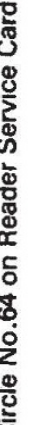

\section{ITE publications} METALS IN ANIMALS

\section{Editor D. Osborn}

ITE Symposium volume no. 12 covering many aspects from effects of metals on wildlife to advanced chemical techniques (NMR).

19840904282775 paper 77pp 44

£3.50

\section{BRITAIN'S RAILWAY VEGETATION}

Caroline Sargent

Habitat, vegetation forms and influences that have combined to produce them are described; decline and success of railway species; predictive model and conservation strategy.

19840904282767 paper 34pp A4

MOORLAND MANAGEMENT: a study of Exmoor

G.R. Miller, J. Miles \& O.W. Heal

Ecological management for agriculture, spor and conservation, with special reference to Exmoor.

19840904282781 paper 118pp A4 $£ 4.50$

Three of the recent publications from the Institute of Terrestrial Ecology. Full list of all publications available.

ITE, Administrative Headquarters, Monks Wood, Abbots Ripton, HUNTINGDON, Cambs. PE17 2LS. 